\title{
1 Reduced upwelling of nutrient and carbon-rich water in the subarctic Pacific
} during the Mid-Pleistocene Transition

\author{
Savannah Worne ${ }^{1 *}$, Sev Kender ${ }^{2,3}, *$, George E. A. Swann ${ }^{1}$, Melanie J. Leng ${ }^{3,4}$, and Ana \\ Christina Ravelo 5 \\ ${ }^{1}$ Centre for Environmental Geochemistry, School of Geography, University of Nottingham, \\ Nottingham, NG7 2RD, UK. \\ ${ }^{2}$ Camborne School of Mines, University of Exeter, Penryn Campus, Penryn, Cornwall, TR10 9FE, \\ UK (s.kender@exeter.ac.uk) \\ ${ }^{3}$ National Environmental Isotope Facility, British Geological Survey, Keyworth, Nottingham, \\ NG12 5GG, UK \\ ${ }^{4}$ Centre for Environmental Geochemistry, School of Biosciences, University of Nottingham, \\ Sutton Bonington Campus, Loughborough, NE12 5RD, UK \\ ${ }^{5}$ University of California, Santa Cruz, CA 95064, USA \\ *Corresponding author \\ Contact: Savannah Worne (savannah.worne@nottingham.ac.uk); Sev Kender \\ (s.kender@exeter.ac.uk); George Swann (george.swann@nottingham.ac.uk); Melanie Leng \\ (mjl@bgs.ac.uk) and Ana Christina Ravelo (acr@ucsc.edu)
}

Key words: MPT; Sea Ice; $\mathrm{CO}_{2}$; Bering Sea; Upwelling index 


\section{Abstract}

Reduction in atmospheric $p \mathrm{CO}_{2}$ has been hypothesised as a causal mechanism for the MidPleistocene Transition (MPT), which saw global cooling and increased duration of glacials between 0.6 and 1.2 Ma. Sea ice-modulated high latitude upwelling and ocean-atmospheric $\mathrm{CO}_{2}$ flux is considered a potential mechanism for $\mathrm{pCO}_{2}$ decline, although there are no long-term nutrient upwelling records from high latitude regions to test this hypothesis. Using nitrogen isotopes and opal mass accumulation rates from 0 to $1.2 \mathrm{Ma}$, we calculate a continuous high resolution nutrient upwelling index for the Bering Sea and assess possible changes to regional $\mathrm{CO}_{2}$ fluxes and to the relative control of sea ice, sea level and glacial North Pacific Intermediate Water (GNPIW) on deep mixing and nutrient upwelling in the region. We find nutrient upwelling in the Bering Sea correlates with global ice volume and air temperature throughout the study interval. From 1 Ma, and particularly during the $900 \mathrm{ka}$ event, suppressed nutrient upwelling would have lowered oceanic fluxes of $\mathrm{CO}_{2}$ to the atmosphere supporting a reduction in global $p \mathrm{CO}_{2}$ during the MPT. This timing is consistent with a pronounced increase in sea ice during the early Pleistocene and restriction of flow through the Bering Strait during glacials after $\sim 900 \mathrm{ka}$, both of which would have acted to suppress upwelling. We suggest that sea-level modulated GNPIW expansion during glacials after $900 \mathrm{ka}$ was the dominant control on subarctic Pacific upwelling strength during the mid-late Pleistocene, while sea ice variability played a secondary role.

\section{Introduction}

The Mid-Pleistocene Transition (MPT) occurred between $~ 1.2$ and 0.6 Ma when glacialinterglacial cycles in global climate increased from a $41 \mathrm{kyr}$ to a longer quasi-100 kyr periodicity (McClymont et al., 2013). The MPT centres on a step-wise increase in benthic foraminiferal $\delta^{18} \mathrm{O}$ at the "900 ka event" ( $\sim 0.9 \mathrm{Ma})$, characterised by a dramatic increase in continental ice sheet volume and resultant rapid declines in global sea level ( $\sim 50$ to $200 \mathrm{~m}$ ) during post-MPT glacial periods when 100 kyr cyclicity emerges (Lisiecki \& Raymo, 2005; Elderfield et al., 2012) together with changes in thermohaline circulation (Schmieder et al., 2000; Sexton \& Barker, 2012). Proposed mechanisms for MPT climate evolution include changing land ice-sheet dynamics (Clark \& Pollard, 1998; Raymo et al., 2006; Crowley \& Hyde, 2008), either controlled by basal erosion or continental ice-sheet instability following expansion of the Antarctic ice sheet (Clark et al., 2006; Pollard \& DeConto, 2009). Alternatively, the MPT may represent a tipping point in a longterm decrease in atmospheric $p \mathrm{CO}_{2}$ (Raymo, 1997; Hönisch et al., 2009) and/or an alteration in ocean-atmosphere $\mathrm{CO}_{2}$ exchange (Pena \& Goldstein, 2014), particularly from high latitude oceans as a result of increased stratification and/or increased efficiency of the biological pump following altered nutrient/dust supply (McClymont et al., 2008; Martinez-Garcia et al., 2010; MartínezGarcia et al., 2011; Rodríguez-Sanz et al., 2012; Chalk et al., 2017; Kender et al., 2018). Others have suggested that a shift in the moisture balance and resultant relationship between northern hemispheric sea ice and land ice formation (the "sea ice switch") following deep ocean cooling could also have been key (Gildor \& Tziperman, 2001).

61

These hypotheses remain largely untested partly due to a lack of high resolution and long-term palaeoenvironmental data. Despite increasing evidence for changing ocean/atmosphere interaction 
in the high latitudes and atmospheric teleconnection with lower latitudes following ice-sheet expansion in the mid-late Pleistocene (Marlow et al., 2000; Heslop et al., 2002; Liu \& Herbert, 2004; McClymont \& Rosell-Melé, 2005; McClymont et al., 2008; Sexton \& Barker, 2012), it is not clear whether these feedbacks were sufficient to control climate change and cause increased ice volumes and/or decreased atmospheric $p \mathrm{CO}_{2}$. Modelling and observational evidence is also biased towards the Southern Ocean, a critical region for the growth of land and sea ice, deep water formation and the upwelling of nutrient- and $\mathrm{CO}_{2}$-rich waters, fuelling an efficient but variable biological pump that dominates atmospheric $\mathrm{CO}_{2}$ variability over Quaternary glacial-interglacial cycles (Billups et al., 2018).

Another key, but comparatively understudied location is the high latitude subarctic Pacific Ocean and the Bering Sea, which is adjacent to the North American Ice Sheets (NAIS) and has been influenced by sea ice since the onset of Northern Hemispheric glaciation ( 2.6 Ma) (Teraishi et al., 2016; Stroynowski et al., 2017). The Bering Sea, bounded to the north by the Bering Strait which connects the Pacific and Arctic Oceans (Stabeno et al., 1999), is a region of palaeoceanographic importance as nutrient- and carbon-rich North Pacific Deep Water (NPDW) upwells at the Bering shelf. The upwelling and vertical mixing of NPDW, driven by eddies and instabilities in the shelf-adjacent Bering Slope Current (BSC), results in seasonally high photic zone $p \mathrm{CO}_{2}$ and primary productivity along the Bering slope (Figure 1). Understanding the longterm changes in subarctic Pacific upwelling, in addition to the Southern Ocean, is therefore important to test the hypothesis that high latitude upwelling contributed to a change in atmospheric $\mathrm{CO}_{2}$ during the MPT.

Previous research from the Bering slope has shown a strong link between NPDW upwelling at the shelf edge and global atmospheric $p \mathrm{CO}_{2}$ in the mid-late Pleistocene ( 0 to $0.85 \mathrm{Ma}$ ), with expanded sea ice suggested to modulate deep water upwelling and ocean-atmosphere $\mathrm{CO}_{2}$ exchanges across the wider subarctic Pacific region (Kender et al., 2018; Worne et al., 2019). This process is suggested to result from increased sea ice and restriction of flow through the Bering Strait due to lower sea level during glacials, hereafter referred to as 'closure of the Bering Strait', promoting the expansion of dense and macronutrient poor glacial North Pacific Intermediate Water (NPIW) across the subarctic Pacific region. Today, NPIW is widely distributed across the North Pacific Ocean at a water depth between $\sim 300-800 \mathrm{~m}$ (Talley, 1993) and is characterised as a salinity minima with a density centred at $26.8 \sigma \theta$ (Yasuda, 1997). Although NPIW is currently sourced primarily from the Okhotsk Sea, there is evidence that indicates the Bering Sea was a key source of NPIW during past glacials (GNPIW) (Ohkushi et al., 2003; Horikawa et al., 2010) as a result of enhanced brine rejection on the Beringian shelf, following increased sea ice growth since $\sim 0.9 \mathrm{Ma}$ (Knudson \& Ravelo, 2015b; Kender et al., 2018). Expansion of GNPIW during post-MPT glacials would have prevented NPDW upwelling and causing region-wide isolation of $\mathrm{CO}_{2}$ in deep waters (Knudson \& Ravelo, 2015b; Kender et al., 2018; Worne et al., 2019). 
However, the short temporal resolution of these existing MPT records from the Bering Sea, and the lack of similar datasets from the early Pleistocene, limit an assessment of the relationship between global climate, atmospheric $p \mathrm{CO}_{2}$ and subarctic nutrient upwelling, prior to significant glacial sea level decline at 0.9 Ma when the Bering Strait first closed (Kender et al., 2018). Here, we present the first continuous nutrient upwelling index (Worne et al., 2019) from the Bering Sea slope from 1.2 Ma onwards . With this, we aim to determine the long-term evolution of nutrient upwelling and its significance for the wider subarctic Pacific Ocean and the global atmospheric $p \mathrm{CO}_{2}$ changes hypothesised to control climate cooling during the MPT (Raymo, 1997; Hönisch et al., 2009).

\section{Materials and methods}

\subsection{Core materials}

Sediment cores from IODP Site U1343 $\left(57^{\circ} 33.39^{\prime} \mathrm{N}, 175^{\circ} 48.95^{\prime} \mathrm{W}\right.$, water depth $\left.1,950 \mathrm{~m}\right)$ were collected during IODP Expedition 323. Situated on a topographic high adjacent to the northern

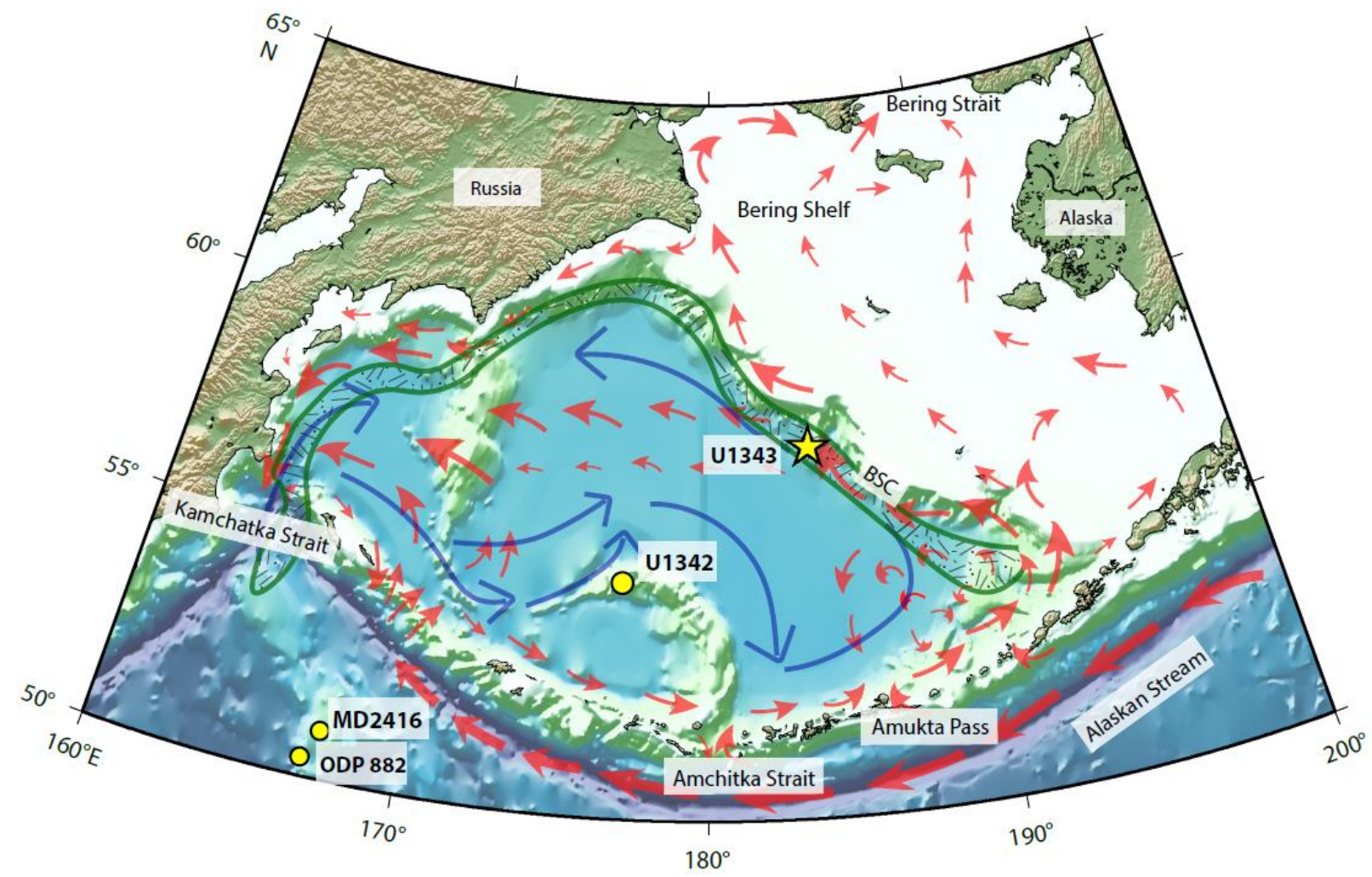

Figure 1 The geographical location and oceanography of the Bering Sea (adapted from Worne et al., (2019)). The white area represents the continental shelf region to the north and the blue represents the Bering Basin. Yellow dots indicate sites of previous important palaeoceanographic study through the Pleistocene including Site ODP 882 and MD2416 from the western subarctic Pacific and IODP Site U1342 from the Southern Bering Sea. Site U1343 (this study) is marked by a yellow star. Surface water circulation is marked by red arrows, which flow in from the Alaskan Stream and through various straits and passes in the Aleutian island arc. Surface water circulates in an anti-clockwise gyre, where turbulence and eddies in the shelf adjacent Bering Slope Current (BSC) causes a high productivity region known as the green belt, represented by the green patterned shape (Springer et al., 1996). Deep water circulation is marked by blue arrows, entering from the lower subarctic Pacific Ocean through the deep western Kamchatka Strait. 
continental shelf, and proximal to the modern winter sea ice edge, IODP Site U1343 sits in the high productivity green belt region, which is directly influenced by high eddy activity in the shelfadjacent BSC, which facilitates high rates of nutrient upwelling and stimulates primary productivity (Figure 1). Shelf-slope exchange of upwelled nutrients provides an important source for Bering shelf productivity, while a similar exchange of shelf-derived nutrients to the green belt, particularly iron, may also have an important source for productivity at Site U1343 during periods of low upwelling (Mizobata \& Saitoh, 2004; Aguilar-Islas et al., 2007; Worne et al., 2019). Marine sediments at Site U1343 are composed primarily of fine clays and biogenic material, and are characteristically distinct from shelf-transported materials (Takahashi et al., 2011; Aiello \& Ravelo, 2012).

\subsection{Site U1343: updated age model (1.02 - 1.2 Ma)}

Good preservation of benthic foraminifera at Site U1343 has allowed construction of a high resolution $\delta^{18} \mathrm{O}$ age model from 0 to $0.85 \mathrm{Ma}(1.1 \mathrm{kyr}$ resolution; Worne et al., 2019) and from 0.85 to $1.02 \mathrm{Ma}\left(0.22 \mathrm{kyr}\right.$ resolution; Kender et al., 2018). Here we present 48 new benthic $\delta^{18} \mathrm{O}$ data points from 1.02 to $1.20 \mathrm{Ma}(284.06$ - $338.32 \mathrm{~m} \mathrm{CCSF}-\mathrm{A})$, to extend the age model back to 1.2 Ma. Following previous studies at this site, $\sim 100 \mu \mathrm{g}$ of foraminiferal calcite from four species (Elphidium batialis, Globobulimina auriculata, Islandiella norcrossi and Uvigerina bifurcate) were measured for $\delta^{18} \mathrm{O}$, applying species-specific offsets previously defined at Site U1343 (Kender et al., 2018) to fit the data to the most commonly occurring species, E. batialis. The $\delta^{18} \mathrm{O}$ measurements were made using an IsoPrime 100 dual inlet mass spectrometer with a Multicarb device at the National Environmental Isotope Facility, British Geological Survey. Results are calculated relative to the VPDB scale using within-run laboratory standard $\left(\mathrm{KCM}, \delta^{18} \mathrm{O}=-1.73 \%\right.$ ) that has been calibrated using the international reference material NBS $19\left(\delta^{18} \mathrm{O}=-2.20 \%\right)$. The KCM standard had an analytical reproducibility of $<0.05 \%$ o $( \pm 1 \sigma, \mathrm{n}=94)$. We combine all existing records to produce a composite $\delta^{18} \mathrm{O}$ record of 1,825 data points, with an average resolution of $0.65 \mathrm{kyr}$ on an updated age model (Figure 2; Supplementary Table 1).

\subsection{Bulk sedimentary $\delta^{15} \mathbf{N}$}

Bulk sedimentary $\delta^{15} \mathrm{~N}$ was previously published for Site U1343 $\left(\delta^{15} \mathrm{~N}_{\mathrm{U} 1343}\right)$ between 0 to 0.85 Ma (Kim et al., 2017; Worne et al., 2019) and 0.85 to $1.02 \mathrm{Ma}$ (Kender et al., 2018). Here we present 62 new bulk sediment $\delta^{15} \mathrm{~N}_{U 1343}$ data points between 1.02 to $1.20 \mathrm{Ma}(284.06-338.32 \mathrm{~m}$ CCSF-A). These were measured using $50 \mathrm{mg}$ of raw material on a Carlo Erba 1108 elemental analyzer, interfaced to a Thermo Finnigan Delta Plus XP IRMS at the University of California, Santa Cruz, with a precision of $0.15 \%$ based on duplicates. Stable isotope data were calibrated using Pugel standard (mean $\delta^{15} \mathrm{~N}=+5.48 \%, \sigma=0.16$ ), with additional in-house long term quality controlled through comparison with sediments from IODP Site U1342 in the southern Bering Sea 
(mean $\delta^{15} \mathrm{~N}=+2.89 \%, \sigma=0.19$ ). We combine all existing records to produce a composite $\delta^{15} \mathrm{~N}_{U 1343}$ record of 623 data points, with an average resolution of $1.9 \mathrm{kyr}$ on the updated age model.

\subsection{Nutrient upwelling index}

The bulk $\delta^{15} \mathrm{~N}_{\mathrm{U} 1343}$ record in the Bering Sea has been suggested to be influenced by a denitrification signal which propagates from the Eastern Tropical North Pacific (ETNP) (Brunelle et al., 2007). Therefore, we follow previous work (Galbraith et al., 2008; Knudson \& Ravelo, 2015a; Worne et al., 2019) subtracting North Pacific Ocean $\delta^{15} \mathrm{~N}$ records from ODP Site 1012 in the eastern tropical North Pacific Ocean $\left(\delta^{15} \mathrm{~N}_{1012}\right)$, thought to be a site of complete nutrient utilisation as well as being influenced by waters originating from the ETNP denitrification zone (Liu et al., 2005; Galbraith et al., 2008). By constraining for background changes in source water $\left(\delta^{15} \mathrm{~N}_{1012}\right)$, the resultant isotope record $\left(\delta^{15} \mathrm{~N}_{U 1343-1012}\right)$ predominantly reflects changes in nutrient utilisation at the Bering slope (Worne et al., 2019).

As nutrient utilisation is a product of both the total nutrient supply (predominantly from upwelling along the slope) and biogenic productivity, the opal MAR records from Site U1343 (Kim et al., 2014) can be used to further constrain the $\delta^{15} \mathrm{~N}_{U 1343-1012}$ record, following the methodology of Worne et al., (2019) in which the opal MAR and $\Delta \delta^{15} \mathrm{~N}_{\text {U1343-1012 }}$ are normalised:

$$
\text { Nutrient Upwelling Index }=\text { Normalised Opal MAR }- \text { Normalised } \Delta \delta^{15} N_{U 1343-1012}
$$

The resultant calculation is termed the nutrient upwelling index (Eq. 1), in which we assume that the upwelling of NPDW was the dominant supply of macronutrients to surface waters at Site U1343, and that rates of nutrient utilisation are controlled by both upwelling strength and the delivery of iron (Fe) from sea ice entrained sources (in addition to contributions from deep water and potential inputs from volcanic sources). Given that the green belt is iron limited (Aguilar-Islas et al., 2007; Takeda, 2011), under a constant rate of nutrient upwelling Fe supply will increase both productivity and nutrient utilisation and will therefore not change the nutrient upwelling index significantly (Worne et al., 2019). Therefore, the resultant "nutrient upwelling index", is a semi-quantitative measure of nutrient supply, where low (high) values suggest a decrease (increase) in NPDW upwelling strength at the Bering slope.

\section{Results}

\subsection{Age model}

The extended Site U1343 benthic foraminiferal $\delta^{18} \mathrm{O}_{\mathrm{U} 1343}$ record contains 1,825 data points with a mean time step of $0.65 \mathrm{kyr}$ between 0 and $1.2 \mathrm{Ma}$. The age model was defined by correlating to the LR04 global composite stack (Lisiecki \& Raymo, 2005), choosing 30 age-depth tie points at periods of rapid isotopic change (e.g. deglacials) (Figure 2, Supplementary Table 1). Poor linear 
regression between foraminiferal $\delta^{13} \mathrm{C}$ and raw $\delta^{18} \mathrm{O}(\mathrm{r}=0.43, \mathrm{p}<0.01)$ shows that diagenetic alteration of foraminiferal shells does not explain the glacial-interglacial variability in the benthic foraminiferal $\delta^{18} \mathrm{O}$ isotope data at Site U1343 (Asahi et al., 2016; Kender et al., 2018; Worne et al., 2019; Detlef et al., 2020).

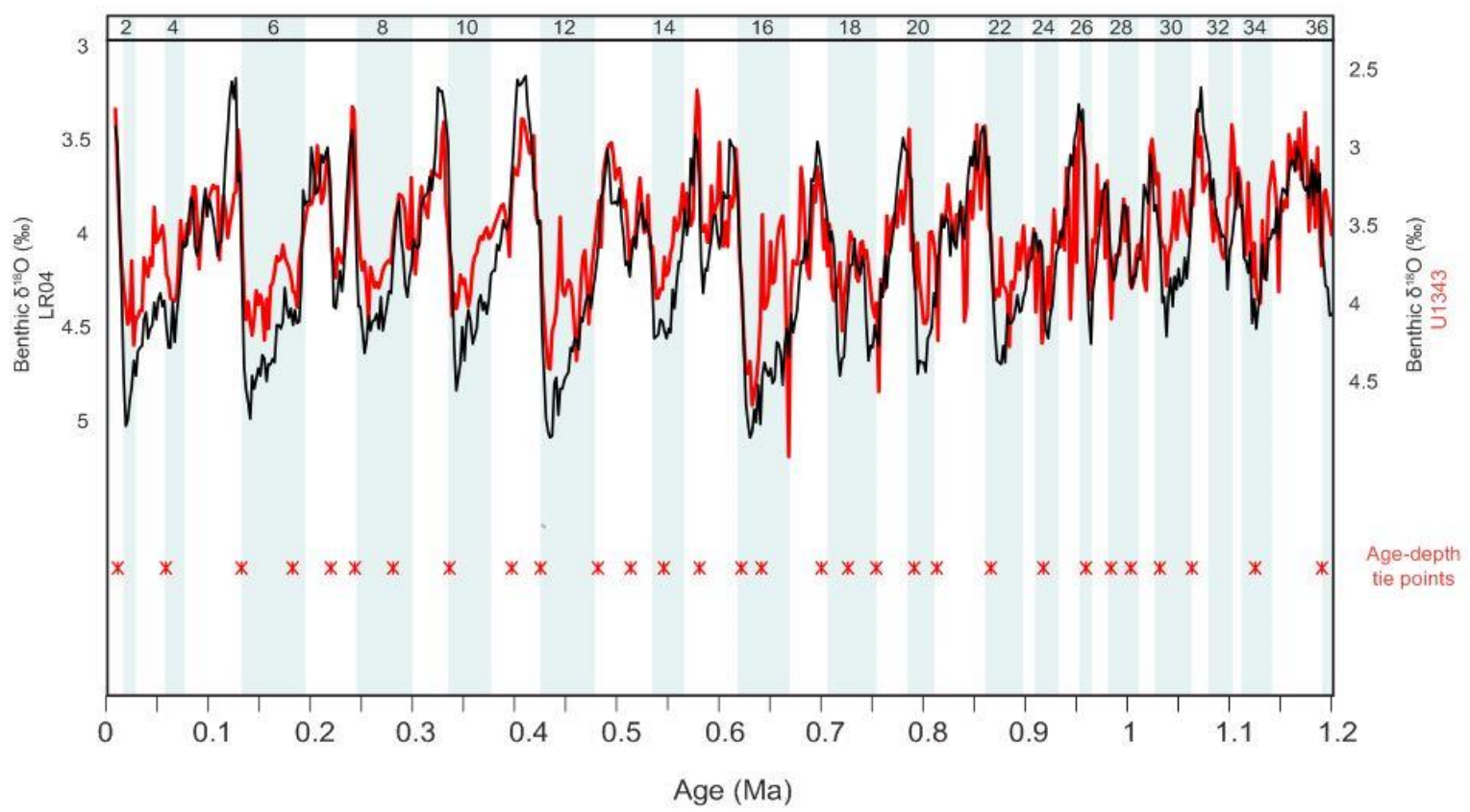

Figure 2 Age Model for Site U1343 from MIS 2 to 36. Benthic foraminiferal $\delta^{18} \mathrm{O}$ results from IODP Site U1343 (red) compared to the LR04 global benthic $\delta^{18} \mathrm{O}$ stack (black) (Lisiecki \& Raymo, 2005), with blue bars represent glacial periods. Age-depth tie points used to tune the age model for Site U1343 with the LR04 stack are shown as red crosses (Supplementary Table 1).

196

197

198

199

200

201

202

203

204

205

206

207

208

209

210

211

\section{2. $\delta^{15} \mathrm{Nu}_{\mathrm{u}} 343$ and the nutrient upwelling index}

Pre-MPT $\delta^{15} \mathrm{~N}_{\mathrm{U} 1343}$ results show a higher mean $(1.02$ to $1.20 \mathrm{Ma}$; mean $=+6.6 \%$ ) than during the 900 ka event $(\sim 0.85$ to $0.95 \mathrm{Ma}$; mean $=+6.0 \%$ or post-MPT $(0$ to $0.85 \mathrm{Ma}$; mean $=+5.6 \%$ ) (Figure 3A). This is consistent with higher opal MAR during this period, where increased productivity caused a larger proportion of the $\delta^{15} \mathrm{~N}$ inferred nutrient pool to be used. The exception to this occurs during MIS 34 when opal MAR is low and $\delta^{15} \mathrm{~N}_{U 1343}$ is high, leading to low upwelling index values. Low opal MAR during this glacial is unlikely to be a result of opal dissolution, as silica diagenesis is not prevalent in the cores at Site U1343 (Takahashi et al., 2011), confirmed by good preservation of diatoms down-core (Teraishi et al., 2016). Therefore, low upwelling index results at MIS 34 are most likely the result of increased sea ice and a highly fluctuating sea ice margin during the build up to MPT conditions (Detlef et al., 2018) (see Section 4.2).

There is also glacial-interglacial variability in $\delta^{15} \mathrm{~N}_{\mathrm{U} 1343}$ with glacials exhibiting significantly lower nutrient utilisation (mean $=+5.7 \%$ ) than interglacial periods (mean $=+5.9 \%$, $\mathrm{p}<0.05$ ), cooccurring with higher productivity during warmer periods (Figure 3A). The exception to this occurs at the MIS 31/32 boundary ( 1.06 Ma) when nutrient utilisation is notably low, although 


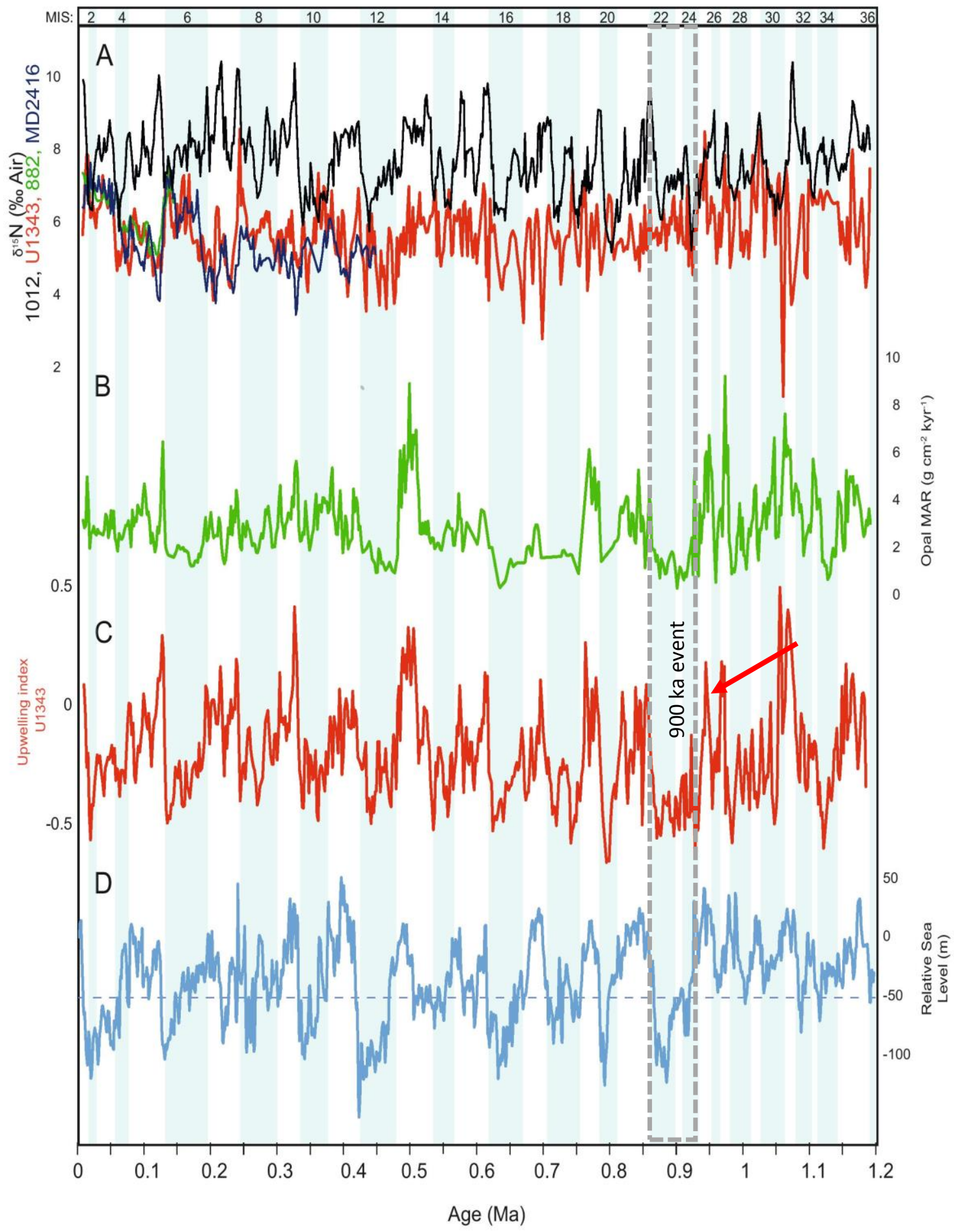

Figure 3 Geochemical proxy results from IODP Site U1343 from MIS 2 to 36 . A) Bulk $\delta^{15} \mathrm{~N}$ data from IODP Site U1343 compared with deep North Pacific ODP Site 1012 (a site of complete nutrient utilisation) (black) together with records from ODP Site 882 (green) and MD2416 (navy blue) in the subarctic Pacific Ocean. B) Opal mass accumulation rate (MAR) from IODP Site U1343 (Kim et al., 2014). C) Upwelling index between 0 - 1.2 Ma (red) are compared to D) relative sea level estimates from Elderfield et al., (2012), where the dashed line represents a $50 \mathrm{~m}$ sea level decline, below which the Bering Strait was likely closed. Blue shaded bars represent glacial periods as defined by the LR04 benthic stack (Lisiecki \& Raymo, 2005), with a grey dashed line to represent the 900 ka event. 
there is no notable change in lithology or biogenic composition of the sediment (Takahashi et al., 2011).

From MIS $33(\sim 1.12 \mathrm{Ma})$ the nutrient upwelling index shows a gradual increase, reaching a peak in early glacial MIS $30(\sim 1.05 \mathrm{Ma})$, where productivity is high and nutrient utilisation is minimal (Figure 3C). Between MIS 30 and MIS 28 ( 1.05 to $0.98 \mathrm{Ma})$, results show a sharp and continued decrease in nutrient upwelling as colder MPT conditions develop (global composite benthic $\delta^{18} \mathrm{O}$, Figure 2), with interglacial upwelling remaining low during MIS 29 ( 1.02 Ma). Despite a recovery in nutrient upwelling strength through MIS $27-25$ ( 0.97 to $0.93 \mathrm{Ma})$, particularly in interglacials where both productivity (opal MAR) and the rate of nutrient utilisation $\left(\delta^{15} \mathrm{~N}_{\mathrm{U} 1343}\right)$ are notably high, a rapid decline in the upwelling index occurs during MIS $24(\sim 0.91$ $\mathrm{Ma}$ ) where productivity is minimal (Figure 3A-C). During the $900 \mathrm{ka}$ event, there is a continued minima in nutrient upwelling index values, particularly through MIS 23 and early MIS $22(\sim 0.86$ to 0.91$)$. At the end of glacial MIS 22 there is a gradual increase in nutrient upwelling strength and recovering productivity towards the deglacial peak. From MIS $21(\sim 0.85 \mathrm{Ma})$ onwards, nutrient upwelling exhibits strong glacial-interglacial variability, with low upwelling during glacials and high upwelling during interglacials (Worne et al., 2019).

Although $\delta^{15} \mathrm{~N}_{\mathrm{U} 1343}$ excursions may also be a result of variable inorganic or terrestrial input, a lack of glacial-interglacial covariation between $\delta^{15} \mathrm{~N}_{\mathrm{U} 1343}$ and $\mathrm{C} / \mathrm{N}$ suggests inorganic nitrogen input does not have an overriding control on $\delta^{15} \mathrm{~N}_{U 1343}$ (Kim et al., 2017; Worne et al., 2019). Furthermore, low $\delta^{15} \mathrm{~N}$ values measured at more distal open ocean subarctic Pacific sites, e.g. Site MD2416, ODP Site 882 (Figure 1) and ODP Site 887, together with diatom-bound $\delta^{15} \mathrm{~N}$ values of less than 5\% at IODP Site U1343 (Kim \& Khim, 2016), provides confidence that nutrient utilisation changes rather than terrestrial/inorganic nitrogen input, is the most significant control on Quaternary glacial-interglacial $\delta^{15} \mathrm{~N}_{\mathrm{U} 1343}$ variability.

\section{Discussion}

\subsection{Nutrient upwelling and glacial-interglacial $\mathrm{CO}_{2}(0.85-1.20 \mathrm{Ma})$}

The upwelling index from $0-0.85 \mathrm{Ma}$ has been previously shown to correlate with a number of proxy and modelled climate records (Worne et al., 2019), including the LR04 deep ocean $\delta^{18} \mathrm{O}$ record (Lisiecki \& Raymo, 2005), relative sea level changes (Elderfield et al., 2012), global surface ocean temperatures (Snyder, 2016) and Antarctic air temperatures (Jouzel et al., 2007). In particular, a strong correlation with global benthic $\delta^{18} \mathrm{O}$ and $p \mathrm{CO}_{2}$ (Lüthi et al., 2008) $(\mathrm{r}=0.60, \mathrm{p}$ $<0.001$ ), was suggested to indicate a common underlying mechanism between NPDW upwelling in the Bering Sea and global climate changes (Worne et al., 2019). Over the extended $0-1.2 \mathrm{Ma}$ interval presented here, a strong correlation is maintained between the upwelling index and relative sea level $(\mathrm{r}=-0.49, \mathrm{p}<0.001)$, surface air temperatures $(\mathrm{r}=0.58, \mathrm{p}<0.001)$, and particularly the LR04 stack $(\mathrm{r}=-0.66, \mathrm{p}<0.001)$. This is consistent with the hypothesis that subarctic Pacific upwelling was integral to the climate system during the MPT (Kender et al., 2018). Although the 
age model for the upwelling index was tuned to the LR04 stack, the high resolution of the dataset ( 2 kyr) and the limited number of tie points used (30; Figure 2, Supplementary Table 1), suggests that the relationship between global ice volume, surface ocean temperature and Bering Sea nutrient upwelling is not an age-model artefact.

Given the link between upwelling subarctic Pacific Ocean deep water and deglacial atmospheric $\mathrm{CO}_{2}$ ventilation for the last deglaciation (Rae et al., 2014; Gray et al., 2018), hypotheses that invoke a reduction in atmospheric $\mathrm{pCO}_{2}$ to drive cooling during the MPT (Raymo, 1997; Hönisch et al., 2009) can be partially tested by examining the evolution of subarctic Pacific upwelling in the build up to the MPT. The upwelling index at Site U1343 shows a long-term glacial fall from $\sim 1.1$ to $0.9 \mathrm{Ma}$ (arrow in Figure 3C), which is in line with the hypothesis that the supply of subarctic Pacific $\mathrm{CO}_{2}$ ventilation to the atmosphere decreased during this interval (Kender et al. 2018), and is consistent with $\mathrm{CO}_{2}$ acting as a driver of MPT climate. While there is no continuous $p \mathrm{CO}_{2}$ proxy record through the MPT for direct comparison, $\delta^{11} \mathrm{~B}$ inferred $p \mathrm{CO}_{2}$ reconstruction from ODP Site 990 in the Caribbean Sea (Chalk et al., 2017) and ODP Site 668B in the eastern equatorial Atlantic (Hönisch et al., 2009), are not inconsistent with the upwelling index during the early Pleistocene (Figure 4B), with higher nutrient upwelling and $p \mathrm{CO}_{2}$ occurring during warmer interglacial periods. Despite an offset between $\mathrm{pCO}_{2}$ and nutrient upwelling minima in MIS 34, the subsequent increase in $p \mathrm{CO}_{2}$ is consistent with increasing nutrient upwelling. Further support for the correlation between nutrient upwelling in the Bering Sea and global $p \mathrm{CO}_{2}$ is found in the predicted $p \mathrm{CO}_{2}$ record from the CYCLOPS carbon cycle model (Chalk et al., 2017) (Figure 4C). The only sustained discrepancy between the two datasets appears during the $900 \mathrm{ka}$ event, when nutrient upwelling remains lower than predicted CYCLOPS $p \mathrm{CO}_{2}$, particularly during late MIS 22 (Figure 4C), coincident with a sustained global sea level drop of >50 m (Elderfield et al., 2012; Kender et al., 2018) (Figure 3D). However, as $p \mathrm{CO}_{2}$ records do not exist in high resolution over the MPT, there is a need for more $\mathrm{CO}_{2}$ proxy data to confirm the nutrient upwelling link with atmospheric $p \mathrm{CO}_{2}$ at that time.

\subsection{Long-term sea ice controls on Bering Sea nutrient upwelling}

Our record demonstrate a consistent relationship between Bering Sea nutrient upwelling and global climate (LR04 benthic stack), with reduced subarctic Pacific upwelling coincident with falling atmospheric $\mathrm{CO}_{2}$ which has been suggested to have caused MPT cooling (Raymo, 1997; Hönisch et al., 2009; Pena \& Goldstein, 2014) and/or an alteration in ocean-atmosphere $\mathrm{CO}_{2}$ exchange. Although this correlation does not prove that reduced subarctic Pacific upwelling caused the MPT, it does support a common mechanism which links subarctic high latitude upwelling with atmospheric $p \mathrm{CO}_{2}$, which subsequently would have contributed to global climate changes through the MPT (Kender et al., 2018; Worne et al., 2019). Previous studies have proposed expansion of GNPIW across the subarctic Pacific as the linking mechanism to suppress upwelling and regional $\mathrm{CO}_{2}$ leakage to the atmosphere (Kender et al., 2018; Worne et al., 2019). However, during MIS 34 , notably low upwelling index values occur prior to $0.9 \mathrm{Ma}$ and are concurrent with higher glacial 
sea levels (Figure 3C-D) which would not have restricted Bering Strait flow (and hence prevented GNPIW formation). This short-lived period of low productivity and high nutrient utilisation while the Bering Strait was likely open, suggests there was an additional control on nutrient upwelling prior to the 900 ka event, in addition to or instead of GNPIW formation.

Glacial-interglacial variability in Bering Sea upwelling index after 0.9 Ma is also suggested to be influenced by sea ice as a secondary control (Worne et al., 2019). Seasonal sea ice cycling plays an active role in controlling total annual primary production (opal MAR) through stabilising the water column and supplying micronutrients, which in turn facilitates a spring melt associated bloom (Aguilar-Islas et al., 2008; Kanematsu et al., 2013). The size of the subsequent summer/autumn bloom is then highly dependent on the degree of post-melt stratification and the availability of remaining nutrients after drawdown in the spring (Hansell et al., 1989), which in turn influences the annual rate of nutrient utilisation $\left(\delta^{15} \mathrm{~N}_{U 1343}\right)$ (Kender et al., 2018; Worne et al., 2019). Diatom evidence from the Bering slope indicates that sea ice began to expand through both glacials and interglacials from at least $~ 1 \mathrm{Ma}$ (Teraishi et al., 2016; Stroynowski et al., 2017; Detlef et al., 2018), when sea ice seasons became more prominent in the build up to the $900 \mathrm{ka}$ event. Therefore, we suggest that increased seasonal sea ice and greater fluctuations in the location and duration of sea ice margin caused higher frequency variability in nutrient upwelling strength and acted as the dominant control on the upwelling index at the Bering slope prior to the $900 \mathrm{ka}$ event. This is in contrast to conditions after 0.9 Ma, when closure of the Bering Strait and increased sea ice during the $900 \mathrm{ka}$ event caused formation of GNPIW, which became the dominant control on nutrient upwelling. Higher resolution sea ice reconstruction work is required to fully resolve the relationship between deep water upwelling and sea ice dynamics in the early and middle Pleistocene.

\subsection{Long-term sea level and GNPIW control on regional subarctic Pacific Ocean upwelling}

Although sea ice dynamics were likely important for determining primary productivity and nutrient utilisation rates at the Bering slope in the build up to the $900 \mathrm{ka}$ event, this does not preclude the hypothesis that GNPIW had a dominant influence on nutrient upwelling during and/or after the MPT in the subarctic Pacific. For example, Knudson \& Ravelo, (2015b) find evidence for GNPIW in the southern Bering Sea (Site U1342; Figure 1) back to at least 1.2 Ma. During the 900 ka event, when significant land ice accumulated, sea level declined by more than $50 \mathrm{~m}$ and caused probable closure of the Bering Strait (Elderfield et al., 2012; Kender et al., 2018). Diatom evidence also suggests that a prolonged pack ice cover occurred during this peak MPT period (Teraishi et al., 2016; Stroynowski et al., 2017). The coincidence of persistent sea ice cover and Bering Strait closure with suppression of nutrient upwelling through MIS 23 up to the end of MIS 22, supports the idea that GNPIW expansion and enhanced stratification resulted in reduced vertical mixing of nutrient-rich waters across the region (Kender et al., 2018). Therefore, the upwelling index supports the notion that retention of $\mathrm{CO}_{2}$ in the deep subarctic Pacific, potentially together with changes in the Southern Ocean (Sigman et al., 2010), was an important mechanism in sustaining 
low subarctic Pacific upwelling, and reducing regional leakage of $\mathrm{CO}_{2}$ to the atmosphere during the MPT which ultimately promoted longer glacial periods and larger glacial ice sheets due to its cooling effect (Kender et al., 2018).

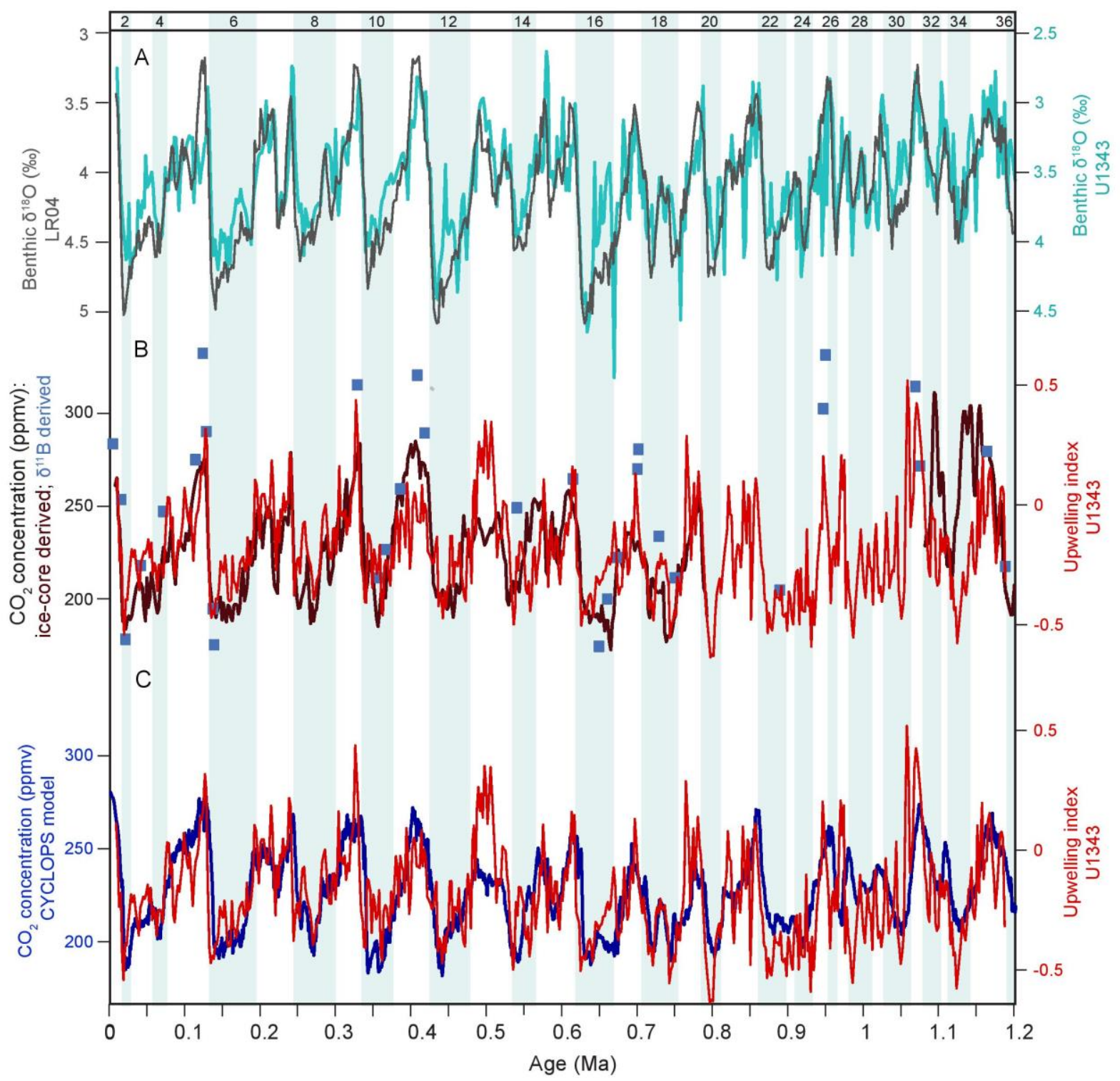

Figure 4 Upwelling index dataset for Site U1343 compared to global climate and $p \mathrm{CO}_{2}$ reconstructions. A) Benthic foraminifera $\delta^{18} \mathrm{O}$ from Site U1343 (red) and the LR04 benthic stack (black). b) Upwelling index between 0 to $1.2 \mathrm{Ma}$ (red) are compared to pCO2 (black) from the Vostok ice core between 0 to $0.8 \mathrm{Ma}$ (Lüthi et al., 2008), and $\delta^{11} \mathrm{~B}$ between $\sim 1.07$ to $1.2 \mathrm{Ma}$ (Chalk et al., 2017). Low resolution boron isotope-derived $p \mathrm{CO} 2$ estimates from Hönisch et al. (2009) are also displayed as light blue squares. C) Comparison of the Bering Sea upwelling index results (red) with modelled atmospheric $\mathrm{CO}_{2}$ concentrations (dark blue) (Chalk et al., 2017).

After the $900 \mathrm{ka}$ event, strong glacial-interglacial variability in the nutrient upwelling index developed, which has been interpreted to reflect continued control of glacially enhanced sea ice and GNPIW formation on nutrient upwelling in the Bering Sea, causing both a reduced 
summer/autumn bloom season and acting as a physical barrier to deep water upwelling at the Bering Sea slope (Worne et al., 2019). The establishment of clear glacial-interglacial variability in nutrient utilisation ( $\delta^{15} \mathrm{~N}_{\mathrm{U} 1343}$ ), despite reduced magnitude of opal MAR variability, indicates that the size of the nutrient pool varied, at least partially, independently from primary productivity (and hence seasonality of the sea ice margin) (Figure 3). Indeed, Worne et al., (2019) noted that the correlation between nutrient upwelling and global $p \mathrm{CO}_{2}$ was particularly strong over the last 0.35 Ma. Therefore, we propose that the expansion of GNPIW (reducing the size of the subsurface nutrient pool) would have continued to act as the first-order control on nutrient upwelling after the MPT (Worne et al., 2019), following trends in global climate and $p \mathrm{CO}_{2}$.

\section{Conclusions}

In summary, we find reduced subarctic nutrient upwelling over the MPT, which would have acted to lower atmospheric $p \mathrm{CO}_{2}$. We hypothesise that this contributed to global cooling before and during the $900 \mathrm{ka}$ event, possibly alongside changes in other upwelling regions such as the Southern Ocean, by reducing $\mathrm{CO}_{2}$. However, existing $\mathrm{pCO}_{2}$ estimates are of too low resolution to resolve if lower levels coincided with the MPT. During the early Pleistocene, evidence exists for increased Bering Sea sea ice extent, but a highly fluctuating sea ice margin between MIS 28 and 24 can account for the high frequency variability in nutrient upwelling found in our records. During the 900 ka event, where our nutrient upwelling index is at its lowest for the whole record (0 to 1.2 $\mathrm{Ma}$ ), accumulation of continental ice sheets and severe sea level decline may have facilitated thick pack ice cover in the Bering Sea. When combined with a closure of the Bering Strait, this likely caused an expansion of a strong GNPIW, layer which suppressed nutrient upwelling at the Bering Slope. Southward propagation of this GNPIW, and reduced regional-scale vertical mixing/deep water ventilation in the subarctic Pacific Ocean, could then have potentially contributed to lower global $p \mathrm{CO}_{2}$ and ultimately a failure of the interglacial at MIS 23 to result in a full deglacial (Kender et al., 2018)(Kender et al., 2018)(Kender et al., 2018).

After the 900 ka event, glacial-interglacial coupling in the nutrient upwelling index and climate proxies supports the hypothesis that nutrient upwelling strength in the Bering Sea was controlled by GNPIW formation, modulated by ice sheet growth/sea level decline which followed(Kender et al., 2018) quasi-100 kyr glacial cycles. Given that sea ice volumes remained higher during both glacials and interglacials after the MPT, variability in sea ice seasonality is still considered to have played a role in our upwelling nutrient record. However, continued closure of the Bering Strait in post-MPT glacials may have promoted GNPIW as the dominant mechanism for suppressing nutrient upwelling, causing more prominent glacial-interglacial variability in the nutrient upwelling record. Further model and high resolution $\mathrm{CO}_{2}$ proxy reconstruction work is needed to better quantify the role of NPIW expansion on the "saw-tooth" shape of post-MPT glacial cycles, as well as the significance of regional changes on global ocean-atmosphere $\mathrm{CO}_{2}$ exchanges. 
Overall, we surmise that MPT sea ice dynamics controlled nutrient upwelling strength in the Bering Sea and subarctic Pacific via two mechanisms: primarily through GNPIW expansion following sea-level modulated Bering Strait closure from $\sim 0.9 \mathrm{Ma}$, which acted to suppress regional upwelling during glacials as expressed in the LR04 global $\delta^{18} \mathrm{O}$ stack. We also posit that sea ice played a secondary role on the upwelling index through controlling seasonal primary productivity and nutrient utilisation at the Bering slope, which caused higher frequency variability in nutrient upwelling, particularly during sea ice expansion leading up to the $900 \mathrm{ka}$ event.

\section{Acknowledgments, Samples, and Data}

We would like to thank the International Ocean Drilling Program for providing samples as well as the Expedition 323 staff and crew of the JOIDES Resolution, and the curators at the Kochi Core Centre. This research was part of a PhD project funded by Natural Environment Research Council (NERC) Envision DTP, CASE funding from the British Geological Survey and NERC Isotope Geosciences Facilities Steering Committee grant IP-1674-1116 (to SK). SW performed the sample preparation, statistical analyses and led the writing of the manuscript. All authors assisted in writing and contributed to interpretations on the manuscript. SK conceived the overall project and isotope analyses were overseen by MJL and CR. We are also grateful to Dyke Andreasen and Colin Carney from the University of California Santa Cruz as well as Christopher Kendrick and Jack Lacey from the National Environmental Isotope Facility, for support with instrumentation and sample preparation. All data needed to evaluate the conclusions in the paper are present in the paper and/or the Supplementary Materials. Additional data related to this paper is available at www.pangaea.de, or may be requested from the authors.

\section{References}

Aguilar-Islas, A. M., Hurst, M. P., Buck, K. N., Sohst, B., Smith, G. J., Lohan, M. C., \& Bruland, K. W. (2007). Micro- and macronutrients in the southeastern Bering Sea: Insight into iron-replete and iron-depleted regimes. Progress in Oceanography, 73(2), 99-126. https://doi.org/10.1016/j.pocean.2006.12.002

Aguilar-Islas, A. M., Rember, R. D., Mordy, C. W., \& Wu, J. (2008). Sea ice-derived dissolved iron and its potential influence on the spring algal bloom in the Bering Sea. Geophysical Research Letters, 35(24), 10-14. https://doi.org/10.1029/2008GL035736

Aiello, I. W., \& Ravelo, A. C. (2012). Evolution of marine sedimentation in the bering sea since the pliocene. Geosphere, 8(6), 1231-1253. https://doi.org/10.1130/GES00710.1

Asahi, H., Kender, S., Ikehara, M., Sakamoto, T., Takahashi, K., Ravelo, a. C. C., ... Leng, M. J. J. (2016). Orbital-scale benthic foraminiferal oxygen isotope stratigraphy at the northern Bering Sea Slope Site U1343 (IODP Expedition 323) and its Pleistocene paleoceanographic significance. Deep-Sea Research Part II: Topical Studies in Oceanography, 125-126, 6683. https://doi.org/10.1016/j.dsr2.2014.01.004

Billups, K., York, K., \& Bradtmiller, L. I. (2018). Water Column Stratification in the Antarctic Zone of the Southern Ocean During the Mid-Pleistocene Climate Transition. 
Paleoceanography and Paleoclimatology, 33(5), 432-442. https://doi.org/10.1029/2018PA003327

Brunelle, B. G., Sigman, D. M., Cook, M. S., Keigwin, L. D., Haug, G. H., Plessen, B., ... Jaccard, S. L. (2007). Evidence from diatom-bound nitrogen isotopes for subarctic Pacific stratification during the last ice age and a link to North Pacific denitrification changes. Paleoceanography, 22(1), 1-17. https://doi.org/10.1029/2005PA001205

Chalk, T. B., Hain, M. P. M. P., Foster, G. L., Rohling, E. J., Badger, M. P. S., Cherry, S. G. S. G. S. G., ... Wilson, P. A. P. A. P. A. (2017). Causes of ice age intensification across the Mid-Pleistocene Transition. Proceedings of the National Academy of Sciences, 114(50), 201702143. https://doi.org/10.1073/pnas.1702143114

Clark, P. U., Archer, D., Pollard, D., Blum, J. D., Rial, J. A., Brovkin, V., ... Roy, M. (2006). The middle Pleistocene transition: characteristics, mechanisms, and implications for longterm changes in atmospheric pCO2. Quaternary Science Reviews, 25(23-24), 3150-3184. https://doi.org/10.1016/j.quascirev.2006.07.008

Clark, P. U., \& Pollard, D. (1998). Origin of the middle Pleistocene transition by ice sheet erosion of regolith. Paleoceanography, 13(1), 1-9. https://doi.org/10.1029/97PA02660

Crowley, T. J., \& Hyde, W. T. (2008). Transient nature of late Pleistocene climate variability. Nature, 456(7219), 226-230. https://doi.org/10.1038/nature07365

Detlef, H., Belt, S. T., Sosdian, S. M., Smik, L., Lear, C. H., Hall, I. R., ... Kender, S. (2018). Sea ice dynamics across the Mid-Pleistocene transition in the Bering Sea. Nature Communications, 9(1). https://doi.org/10.1038/s41467-018-02845-5

Detlef, H., Sosdian, S. M., Kender, S., Lear, C. H., \& Hall, I. R. (2020). Multi-elemental composition of authigenic carbonates in benthic foraminifera from the eastern Bering Sea continental margin (International Ocean Discovery Program Site U1343). Geochimica et Cosmochimica Acta, 268, 1-21. https://doi.org/10.1016/j.gca.2019.09.025

Elderfield, H., Ferretti, P., Greaves, M., Crowhurst, S. J., McCave, I. N., Hodell, D. a, \& Piotrowski, A. M. (2012). Evolution of ocean temperature. Science, 337(August), 704-709. https://doi.org/10.1594/PANGAEA.786205

Galbraith, E. D., Kienast, M., Jaccard, S. L., Pedersen, T. F., Brunelle, B. D., Sigman, D. M., \& Kiefer, T. (2008). Consistent relationship between global climate and surface nitrate utilization in the western subarctic Pacific throughout the last 500 ka. Paleoceanography, 23(2), 1-11. https://doi.org/10.1029/2007PA001518

Gildor, H., \& Tziperman, E. (2001). A sea ice climate switch mechanism for the 100-kyr glacial cycles. Journal of Geophysical Research, Vol. 106, p. 9117. https://doi.org/10.1029/1999JC000120

Gray, W. R., Rae, J. W. B., Wills, R. C. J., Shevenell, A. E., Taylor, B., Burke, A., ... Lear, C. H. (2018). Deglacial upwelling, productivity and CO2 outgassing in the North Pacific Ocean. Nature Geoscience, 11(5), 340-344. https://doi.org/10.1038/s41561-018-0108-6

Hansell, D. A., Goering, J. J., Walsh, J. J., McRoy, C. P., Coachman, L. K., \& Whitledge, T. E. (1989). Summer phytoplankton production and transport along the shelf break in the Bering Sea. Continental Shelf Research, 9(12), 1085-1104. https://doi.org/10.1016/0278- 
Heslop, D., Dekkers, M. J., \& Langereis, C. G. (2002). Timing and structure of the midPleistocene transition: Records from the loess deposits of northern China. Palaeogeography, Palaeoclimatology, Palaeoecology, 185(1-2), 133-143. https://doi.org/10.1016/S0031-0182(02)00282-1

Hönisch, B., Hemming, G. N., Archer, D., Siddall, M., \& McManus, J. F. (2009). Atmospheric Carbon Dioxide Concentration Across the Mid-Pleistocene Transition. Science, 324(5934), 1551-1554. https://doi.org/10.1126/science.1229223

Horikawa, K., Asahara, Y., Yamamoto, K., \& Okazaki, Y. (2010). Intermediate water formation in the Bering Sea during glacial periods: Evidence from neodymium isotope ratios. Geology, 38(5), 435-438. https://doi.org/10.1130/G30225.1

Jouzel, J., Masson-Delmotte, V., Cattani, O., Dreyfus, G., Falourd, S., Hoffmann, G., ... Wolff, E. W. (2007). Orbital and Millennial Antarctic Climate Variability over the Past 800,000 years. Science, 317(August), 793-796. https://doi.org/10.1126/science.1141038

Kanematsu, Y., Takahashi, K., Kim, S., Asahi, H., \& Khim, B. K. (2013). Changes in biogenic opal productivity with Milankovitch cycles during the last 1.3Ma at IODP Expedition 323 Sites U1341, U1343, and U1345 in the Bering Sea. Quaternary International, 310, $213-$ 220. https://doi.org/10.1016/j.quaint.2013.06.003

Kender, S., Ravelo, A. C., Worne, S., Swann, G. E. A., Leng, M. J., Asahi, H., ... Hall, I. R. (2018). Closure of the Bering Strait caused Mid-Pleistocene Transition cooling. Nature Communications, 9(5386). https://doi.org/10.1038/s41467-018-07828-0

Kim, S., \& Khim, B. K. (2016). Reconstruction of nitrate utilization rate change based on diatom-bound nitrogen isotope values in the central slope area of the Bering sea during the early pleistocene (2.4-1.25 Ma). Ocean and Polar Research, 38(3), 195-207. https://doi.org/10.4217/OPR.2016.38.3.195

Kim, S., Khim, B. K., Ikehara, M., \& Takahashi, K. (2017). Relationship between $\delta 15 \mathrm{~N}$ values of bulk sediments and total organic carbon concentration in response to orbital-scale biogenic opal production in the Bering slope area over the last 600 kyrs. Quaternary International, 459(3), 144-152. https://doi.org/10.1016/j.quaint.2017.05.041

Kim, S., Takahashi, K., Khim, B. K., Kanematsu, Y., Asahi, H., \& Ravelo, A. C. (2014). Biogenic opal production changes during the Mid-Pleistocene Transition in the Bering Sea (IODP Expedition 323 Site U1343). Quaternary Research (United States), 81(1), 151-157. https://doi.org/10.1016/j.yqres.2013.10.001

Knudson, K. P., \& Ravelo, A. C. (2015a). Enhanced subarctic Pacific stratification and nutrient utilization during glacials over the last 1.2 Myr. Geophysical Research Letters, 42(22), 9870-9879. https://doi.org/10.1002/2015GL066317

Knudson, K. P., \& Ravelo, A. C. (2015b). North Pacific Intermediate Water circulation enhanced by the closure of the Bering Strait. Paleoceanography, 30(10), 1287-1304. https://doi.org/10.1002/2015PA002840

Lisiecki, L. E., \& Raymo, M. E. (2005). A Pliocene-Pleistocene stack of 57 globally distributed benthic $\delta 18 \mathrm{O}$ records. Paleoceanography, 20(1), 1-17. 
https://doi.org/10.1029/2004PA001071

Liu, Z., Altabet, M. A., \& Herbert, T. D. (2005). Glacial-interglacial modulation of eastern tropical North Pacific denitrification over the last 1.8-Myr. Geophysical Research Letters, 32(23), 1-4. https://doi.org/10.1029/2005GL024439

Liu, Z., \& Herbert, T. D. (2004). High-latitude influence on the eastern equatorial Pacific climate in the early Pleistocene epoch. Nature, 430(July), 560-564. https://doi.org/10.1038/nature02295.1.

Lüthi, D., Le Floch, M., Bereiter, B., Blunier, T., Barnola, J. M., Siegenthaler, U., ... Stocker, T. F. (2008). High-resolution carbon dioxide concentration record 650,000-800,000 years before present. Nature, 453(7193), 379-382. https://doi.org/10.1038/nature06949

Marlow, J. R., Lange, C. B., Wefer, G., \& Rosell-Mele, a. (2000). Upwelling intensification as part of the Pliocene-Pleistocene climate transition. Science, 290(5500), 2288-2291. https://doi.org/10.1126/science.290.5500.2288

Martínez-Garcia, A., Rosell-Melé, A., Jaccard, S. L., Geibert, W., Sigman, D. M., \& Haug, G. H. (2011). Southern Ocean dust-climate coupling over the past four million years. Nature, 476(7360), 312-315. https://doi.org/10.1038/nature10310

Martinez-Garcia, A., Rosell-Melé, A., McClymont, E. L., Gersonde, R., \& Haug, G. H. (2010). Subpolar Link to Emergence of the Modern Equatorial Pacific Cold Tongue. Science, 328(5985), 1550-1553.

McClymont, E. L., \& Rosell-Melé, A. (2005). Links between the onset of modern Walker circulation and the mid-Pleistocene climate transition. Geology, 33(5), 389-392. https://doi.org/10.1130/G21292.1

McClymont, E. L., Rosell-Melé, A., Haug, G. H., \& Lloyd, J. M. (2008). Expansion of subarctic water masses in the North Atlantic and Pacific oceans and implications for mid-Pleistocene ice sheet growth. Paleoceanography, 23(4), 1-12. https://doi.org/10.1029/2008PA001622

McClymont, E. L., Sosdian, S. M., Rosell-Melé, A., \& Rosenthal, Y. (2013). Pleistocene seasurface temperature evolution: Early cooling, delayed glacial intensification, and implications for the mid-Pleistocene climate transition. Earth-Science Reviews, 123, 173193. https://doi.org/10.1016/j.earscirev.2013.04.006

Mizobata, K., \& Saitoh, S. I. (2004). Variability of Bering Sea eddies and primary productivity along the shelf edge during 1998-2000 using satellite multisensor remote sensing. Journal of Marine Systems, 50(1-2), 101-111. https://doi.org/10.1016/j.jmarsys.2003.09.014

Ohkushi, K., Suzuki, A., Kawahata, H., \& Gupta, L. P. (2003). Glacial-interglacial deep-water changes in the NW Pacific inferred from single foraminiferal $\delta 18 \mathrm{O}$ and $\delta 13 \mathrm{C}$. Marine Micropaleontology, 48(3-4), 281-290. https://doi.org/10.1016/S0377-8398(03)00023-9

Pena, L. D., \& Goldstein, S. L. (2014). Thermohaline circulation crisis and impacts during the mid-Pleistocene transition. Science, 345(6194), 318-322. https://doi.org/10.1126/science. 1249770

Pollard, D., \& DeConto, R. M. (2009). Modelling West Antarctic ice sheet growth and collapse through the past five million years. Nature, 458(7236), 329-332. https://doi.org/10.1038/nature07809 
Rae, J. W. B., Sarnthein, M., Foster, G. L., Ridgewell, A., Grootes, P. M., \& Elliott, T. (2014). Deep water formation in the North Pacific and deglacial CO2 rise. Paleoceanography, 29, 1-23. https://doi.org/10.1002/2013PA002570.Received

Raymo, M. E. (1997). The timing of major climate terminations. Paleoceanography, 12(4), 577585. https://doi.org/10.1029/97PA01169

Raymo, M. E., Lisiecki, L. E., Nisancioglu, K. H., Hemispheres, S., \& Instead, O. (2006). PlioPleistocene Ice Volume, Antarctic Climate, and the Global d180 Record. Nature, 313(July), 492-495. https://doi.org/10.1126/science.1123296

Rodríguez-Sanz, L., Graham Mortyn, P., Martínez-Garcia, A., Rosell-Melé, A., \& Hall, I. R. (2012). Glacial Southern Ocean freshening at the onset of the Middle Pleistocene Climate Transition. Earth and Planetary Science Letters, 345-348, 194-202. https://doi.org/10.1016/j.epsl.2012.06.016

Schmieder, F., Von Dobeneck, T., \& Bleil, U. (2000). The Mid-Pleistocene climate transition as documented in the deep South Atlantic Ocean: Initiation, interim state and terminal event. Earth and Planetary Science Letters, 179(3-4), 539-549. https://doi.org/10.1016/S0012821X(00)00143-6

Sexton, P. F., \& Barker, S. (2012). Onset of "Pacific-style" deep-sea sedimentary carbonate cycles at the mid-Pleistocene transition. Earth and Planetary Science Letters, 321-322, 8194. https://doi.org/10.1016/j.eps1.2011.12.043

Sigman, D. M., Hain, M. P., \& Haug, G. H. (2010). The polar ocean and glacial cycles in atmospheric CO2 concentration. Nature, 466(7302), 47-55. https://doi.org/10.1038/nature09149

Snyder, C. W. (2016). Evolution of global temperature over the past two million years. Nature, 538(7624), 226-228. https://doi.org/10.1038/nature19798

Stabeno, P. J., Schumacher, J. D., \& Ohtani, K. (1999). The physical oceanography of the Bering Sea. Dynamics of the Bering Sea, 1-60. Retrieved from ftp://128.112.177.15/pub/edac/bering_sea/Stabeno_1999_bering_sea.pdf

Stroynowski, Z., Abrantes, F., \& Bruno, E. (2017). The response of the Bering Sea Gateway during the Mid-Pleistocene Transition. Palaeogeography, Palaeoclimatology, Palaeoecology, 485(March), 974-985. https://doi.org/10.1016/j.palaeo.2017.08.023

Takahashi, K., Ravelo, A. C., Alvarez Zarikian, C. A., \& Scientists, E. 323. (2011). Site U1343. Proceedings of the IODP, 323, 323. https://doi.org/10.2204/iodp.proc.323.107.2011

Takeda, S. (2011). Iron and Phytoplankton Growth in the Subarctic North Pacific. AquaBioScience Monographs, 4(2), 41-93. https://doi.org/10.5047/absm.2011.00402.0041

Talley, L. D. (1993). Distribution and Formation of North Pacific Intermediate Water. Journal of Physical Oceanography, 23, 517-537.

Teraishi, A., Suto, I., Onodera, J., \& Takahashi, K. (2016). Diatom, silicoflagellate and ebridian biostratigraphy and paleoceanography in IODP 323 Hole U1343E at the Bering slope site. Deep-Sea Research Part II: Topical Studies in Oceanography, 125-126, 18-28. https://doi.org/10.1016/j.dsr2.2013.03.026 
580 Worne, S., Kender, S., Swann, G. E. A., Leng, M. J., \& Ravelo, A. C. (2019). Coupled climate and subarctic Pacific nutrient upwelling over the last 850, 000 years. Earth and Planetary Science Letters, 522, 87-97.

583 Yasuda, I. (1997). The origin of the North Pacific Intermediate Water. Journal of Geophysical 584 Research: Oceans, 102(C1), 893-909. https://doi.org/10.1029/96jc02938 


\section{Supplementary Information}

Supplementary Table 1 New age-depth tie points for Site U1343, building on Worne et al. (2019).

\begin{tabular}{|c|c|}
\hline Depth (CCSF - A) (m) & Age (ka) \\
\hline 0.96 & 10.15 \\
\hline 14.23 & 57.38 \\
\hline 36.72 & 131.41 \\
\hline 48.03 & 181.46 \\
\hline 59.73 & 219.06 \\
\hline 68.72 & 242.57 \\
\hline 79.52 & 279.96 \\
\hline 96.24 & 335.14 \\
\hline 114.56 & 396.17 \\
\hline 119.35 & 424.39 \\
\hline 129.90 & 480.93 \\
\hline 145.02 & 512.78 \\
\hline 152.01 & 545.32 \\
\hline 161.63 & 580.48 \\
\hline 173.39 & 621.39 \\
\hline 174.57 & 641.03 \\
\hline 184.09 & 700.03 \\
\hline 188.27 & 725.84 \\
\hline 191.58 & 753.63 \\
\hline 203.57 & 790.75 \\
\hline 209.04 & 812.86 \\
\hline 227.39 & 865.95 \\
\hline 238.34 & 917.46 \\
\hline 254.16 & 959.01 \\
\hline 266.14 & 983.50 \\
\hline 272.57 & 1002.99 \\
\hline 282.73 & 1031.59 \\
\hline 296.57 & 1062.96 \\
\hline 318.81 & 1124.99 \\
\hline 336.91 & 1190.47 \\
\hline
\end{tabular}

